\title{
DAILY RHYTHMIC ACTIVITY OF THE SEA-PEN, CAVERNULARIA OBESA VALENCIENNES XV. CONTROLLING OF THE ACTIVITY BY LIGHT (3)
}

\section{$\operatorname{AUTHOR}(\mathrm{S}):$}

Mori, Syuiti; Mori, Syuiti; Ondo, Yosinori

\section{CITATION:}

Mori, Syuiti ...[et al]. DAILY RHYTHMIC ACTIVITY OF THE SEA-PEN, CAVERNULARIA OBESA VALENCIENNES XV. CONTROLLING OF THE ACTIVITY BY LIGHT (3). PUBLICATIONS OF THE SETO MARINE BIOLOGICAL LABORATORY 1957, 6(1): 79-98

\section{ISSUE DATE:}

1957-06-30

URL:

http://hdl.handle.net/2433/174571

RIGHT: 


\title{
DAILY RHYTHMIC ACTIVITY OF THE SEA-PEN, CAVERNULARIA OBESA VALENCIENNES
}

XV. CONTROLIING OF THE ACTIVITY BY LIGHT $(3)^{1 / 2}$

\author{
SYUITI MORI \\ Zoological Institute, Kyoto University \\ and \\ YOSINORI ONDÔ \\ Biological Laboratory, Tottori University
}

With Plate $V$ and 10 Text-figures

\section{Introduction}

The daily rhythmic activities, which are widely observable in the living world, have attracted interests of many investigators, and up to the present time a considerable number of researches have been published. Some important results among them were summarized by PARK (1940), CALHOUN (1944-1946), MORI (1948), KLEITMAN (1949) and Aschoff (1954, 1955).

From these works we know that daily rhythmic activities of many animals are controlled, on one hand by the change of environmental factors especially of light, and on the other hand by some intrinsic rhythmic factors (rhythmic changes of physiological states). But as to the interrelations of these external and internal factors, relatively few attentions have hitherto been paid.

The senior author has been studying the daily rhythmic activity of the sea-pen, Cavernularia obesa, since 1943, and has found that not only the change of light modifies the mode of its activity, but also some internal physiological rhythms lie beneath the normal exhibition of rhythmic activity. Namely, the sea-pen is performing its rhythmic pattern of life in nature under double assurances of mechanisms - rhythmic changes of internal physiological states and periodic changes of external solar illumination (MORI, $1943 \mathrm{a}, \mathrm{b} ; 1944 \mathrm{a}, \mathrm{b}, \mathrm{c}, \mathrm{d}, \mathrm{e} ; 1945 \mathrm{~b} ; 1947 \mathrm{a}, \mathrm{b} ; 1948 \mathrm{a} ; 1949$; 1950: TAKADA and MoRI, 1956; 1957).

1) Contributions from the Seto Marine Biological Laboratory; No. 295.

2) This research was aided by the Scientific Research Expenditure of the Department of Education.

Publ. Seto Mar. Biol. Lab., VI (1), 1957. (Article 6) 
Then, what would happen in its activity rhythm when phases of these two factors were made discordant with each other? To clarify these problems, the senior author has made a series of experiments which consisted of three sets of schemes: 1) reversing the environmental light-dark phase by using artificial light of various illumination intensities (viz. $1230 \mathrm{Lux}, 130 \mathrm{Lux}, 7 \mathrm{Lux}, 1.2 \mathrm{Lux}, 0.3 \mathrm{Lux}$; see MorI, 1944a, 1949), 2) changing the lengths of alternative light (ca. 1200 Lux) and dark period, keeping the lengths of both phases as equal (viz. 18 hours light-18 hours dark, 15-15, 9-9, 6-6 ; see MORI, 1944a, 1949), 3) changing the relative lengths of alternative light (ca. $1200 \mathrm{Lux}$ ) and dark phases, but keeping the total length of one cycle as constant-24 hours (vis. 18 hours light-6 hours dark, 15-9, 9-15, 6-18, 3-21; see MORI, 1944a, 1949). The results of these experiments were summarized in the report of 1950, with the conclusion that, although light influenced intensely the mode of rhythmic activity of the sea-pen by modifying its phases, the animal persisted more and more its original natural mode of activity as the intensities of artificial light became weaker or as the phase relations of alternative light and dark periods deviated further from the natural phase.

The present paper deals with the results of our further investigation concerning with the control of the activity by light, and with the synthetic discussion based on these and other experiments previously reported. The experiments mentioned in this report belong to the categories of the 2) and 3) schemes mentioned above.

The authors express here their sincere thanks to Prof. D. Miyadi who read the original manusctipt and gave kind advices and to the members of the Seto Marine Biological Laboratory who afforded various facilities through the course of the study.

\section{Materials and Methods}

1. The sea-pens were collected from a shallow sandy bottom in the vicinity of the Seto Marine Biological Laboratory, few days or about a month prior to the experiments, and then reared in a large aquarium of the Laboratory until the experiments were started. Healthy colonies only were used for the experiments.

2. Before the experiments, the animals were transplanted one by one in the long glass cylinders placed in the laboratory as is shown in Plate V. The water was continuously circulated and kept overflowing. The animals could be maintained quite healthfully in these conditions, and showed normal rhythmic activity of daily contraction and nightly expansion. The length of the stem expanded above the sand was measured at certain intervals (usually at every 3 hours), which was taken as an index of the activity. The conditions of the individual polyps were not recorded in the present experiments.

3. The experiments to be reported here consist of three series. Firstly, the animals were subjected to the alternative light and dark conditions of equal lengths. As for this sort of experiment, the senior author had already described the features of activities under alternative 18 hours light and 18 hours dark cycle (designated 
hereafter as 18-18 hours, light-dark cycle), 15-15 hours, 9-9 hours, and 6-6 hours, light-dark cycles. In this report we will add the results obtained under the 24-24 hours, $21-21$ hours, $3-3$ hours, $1.5-1.5$ hours, $30-30$ minutes, $15-15$ minutes, and 5-5 minutes light-dark cycles.

Secondly, the alternative light and dark conditions of different duration, maintaining the total length of one cycle as 24 hours, were used as the light environment. As for this sort of experiments, the senior author had described the rhythmic features of activity under 18-6 hours, 15-9 hours, 9-15 hours, 6-18 hours, and 3-21 hours light-dark environmental cycles. In this report we will add the mode of activity under 21-3 hours light-dark condition.

Lastly, the animals were subjected to alternative 30-30 minutes light-dark condition for a relatively long period, ca. 10 days. This experiment was planned in order to scrutinize the relation existing between the environmental light conditions and the internal physiological states.

4 The intensity of light employed ranged between 1000-1700 Lux (mostly about $1200 \mathrm{Lux}$ ), being obtained from an electric lamp of 200-300 watts. Variations of light intensity in these degrees had practically no effect on such activities to be described here. Turning on or off of electric current was in most cases controlled by an automatic bell timer, and in other cases by the investigator himself. The water temperature was not controlled, but the experiments were always performed during the warmer season of a year, so that it was always maintained above $20^{\circ} \mathrm{C}$. The senior author had previously ascertained that the feature of activity was manifested nearly similarly so long as the water temperature was maintained above $13^{\circ} \mathrm{C}$ (MORI, 1944b, c), so that the possible effect due to the variation in water temperature may be neglected.

\section{Results}

\section{The results of the first series of experiments}

a) Activities under alternative 21 hours illumination and 21 hours darkness (one cycle consists of 42 hours)

4 colonies were used. The experiment was performed during Sept. 20 to 26 , 1954. The intensity of light used was about $1400 \mathrm{Lux}$, the water temperature varied between $24.3^{\circ}$ to $27.7^{\circ} \mathrm{C}$. Fig. 1 shows the results.

It may be seen that the activity of 2 colonies (Nos. 1 and 2) is disturbed or may be said as showing approximately 42 hours rhythm (dependent rhythm to the environment), 1 colony (No. 3) shows somewhat 9 to 12 hours rhythm (half of the normal rhythm) and the last 1 colony (No. 4) is affected at first, but ultimately shows natural 24 hours rhythm.

The appearance of the colony that seems to persist its normal rhythm is characteristic under the "adequately" shifted periodic light conditions. Although it was found by MORI (1949) that, under 18-18 hours light-dark condition, the activities 


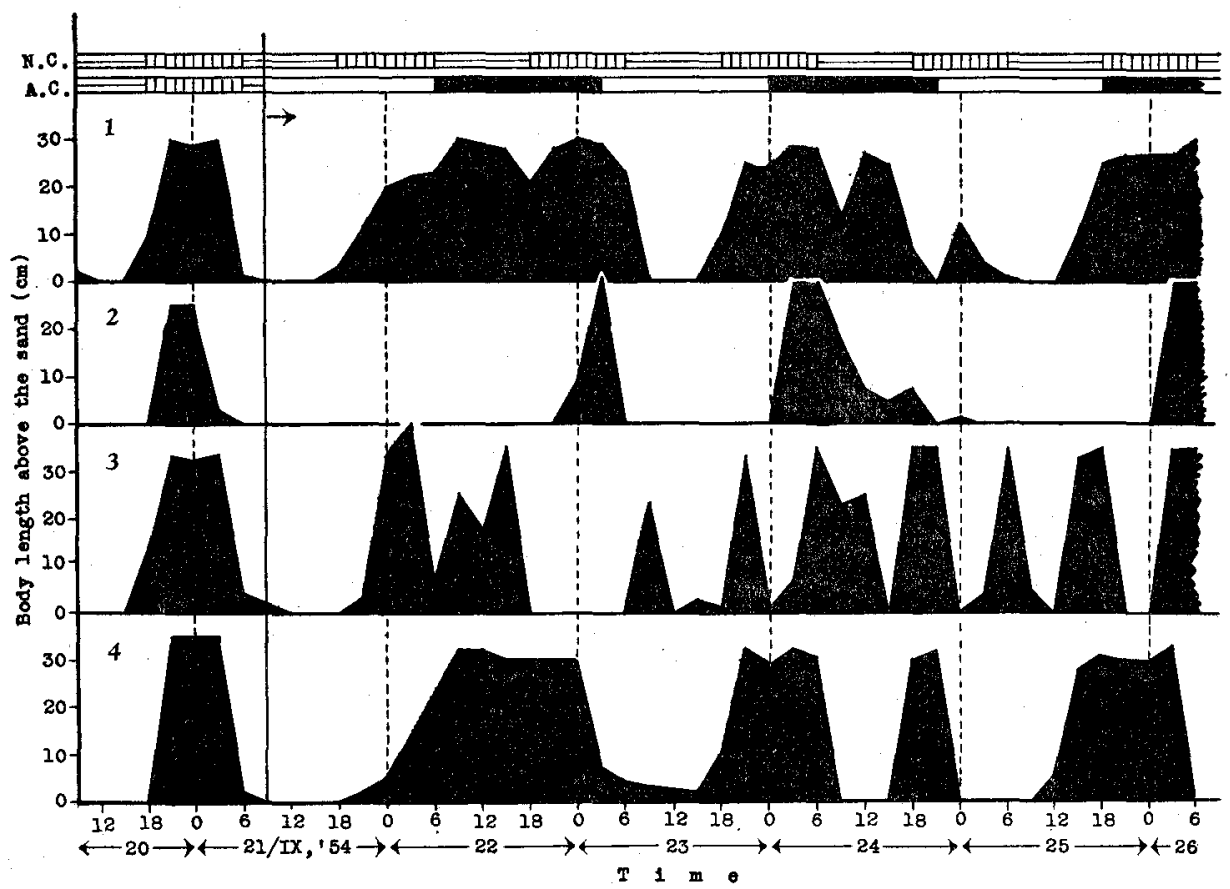

Fig. 1. Features of activity under 21-21 hours light-dark condition.

Black areas show durations and degrees of expansion of animals above sand. N.C. : Natural day ( $\mid$ ) and night (|II|) cycle. A.B.: Artificial light ( $\square$ ) and dark ( a cycle. Arrow in the figure indicates when the animals were subjected to the experimental light conditions.

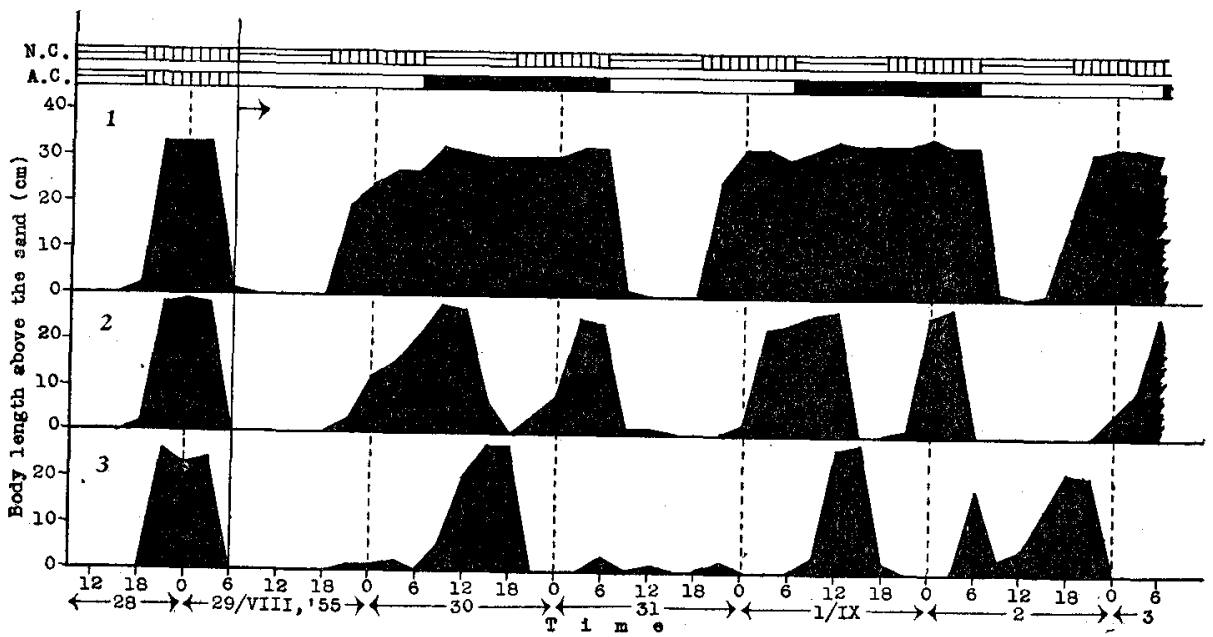

Fig. 2. Features of activity under 24-24 hours light-dark condition. 
were not usually coincident with the environmental light periodicity (though 1 colony out of 4 showed to some extent a tendency to persist its original rhythm), under more abnormal conditions such as $21-21$ hours light-dark cycle, the sea-pen that persisting clearly its original rhythmic activity appears.

b) Activities under alternative 24 hours illumination and 24 hours darkness (one cycle 48 hours)

Under a greater length of a cycle, what would happen in the mode of rhythmic activity? 3 colonies were used. The experiment was performed during Aug. 28 to Sept. 3, 1955. The intensity of light used was $1400 \mathrm{Lux}$, the water temperature varied between $26.7^{\circ}$ to $28.1^{\circ} \mathrm{C}$. The results are shown in Fig. 2 .

The colony No. 1 shows modified 48 hours cycle. But because it begins to expand even when it is illuminated, its activity may be said as not truly dependent on the environmental light condition but as are controlled by the double forcesexternal and internal. No. 2 colony shows modified 24 hours cycle; it expands twice in the dark periods, but as it begins to expand even when it is illuminated as in the case of No. 1 colony, the persistency of the original rhythm seems to be fairly deep. rooted. The colony No. 3 is disturbed; no definite rhythmicity can be recognized.

In conclusion, the activity rhythms are in some cases regular (but not accurately dependent or accurately persisting) and in other cases irregular. The senior author had previously supposed that as the environmental light periodicity becomes more and more discrepant from the normal one, so the activity may become more and more independent of the environment and persistent of the original rhythm. But the results of the present experiments did not prove it. At extremely shifted environmental conditions the activity was generally disturbed, being discordant from the normal rhythm, though usually showing deeply-rooted persistency to it. These results, of course, will be more or less modified according to the intensities of light to be used, but the general conclusion will be held. These circumstances can also be seen when the durations of the environmental cycles are shortened.

c) Activities under alternative 3 hours illumination and 3 hours darkness (on cycle 6 hours)

The experiment was performed during July 20 to 24, 1952, using 2 colonies, and repeated during July 13 to 18,1953 , using 4 colonies. The intensity of light used was $1470 \mathrm{Lux}$, the water temperature varied between $26.0^{\circ}$ to $28.5^{\circ}$ and $25.0^{\circ}$ to $26.6^{\circ} \mathrm{C}$ respectively. The results are shown in Figs. 3a and b.

The colony No. 1 has a tendency to persist 24 hours rhythm, though, as may be judged from the irregular behavior during the expansion period, seems strongly influenced by the environmental 6 hours cycle. The behavior of No. 2 is irregular. No. 3 shows 12 hours cycle. No. 4 exhibits somewhat 6 hours cycle, being dependent on the environmental light periodicity. No. 5 resembles to No. 1, i.e., shows 24 hours cycles, though greatly modified by the environmental light periodicity; in other 

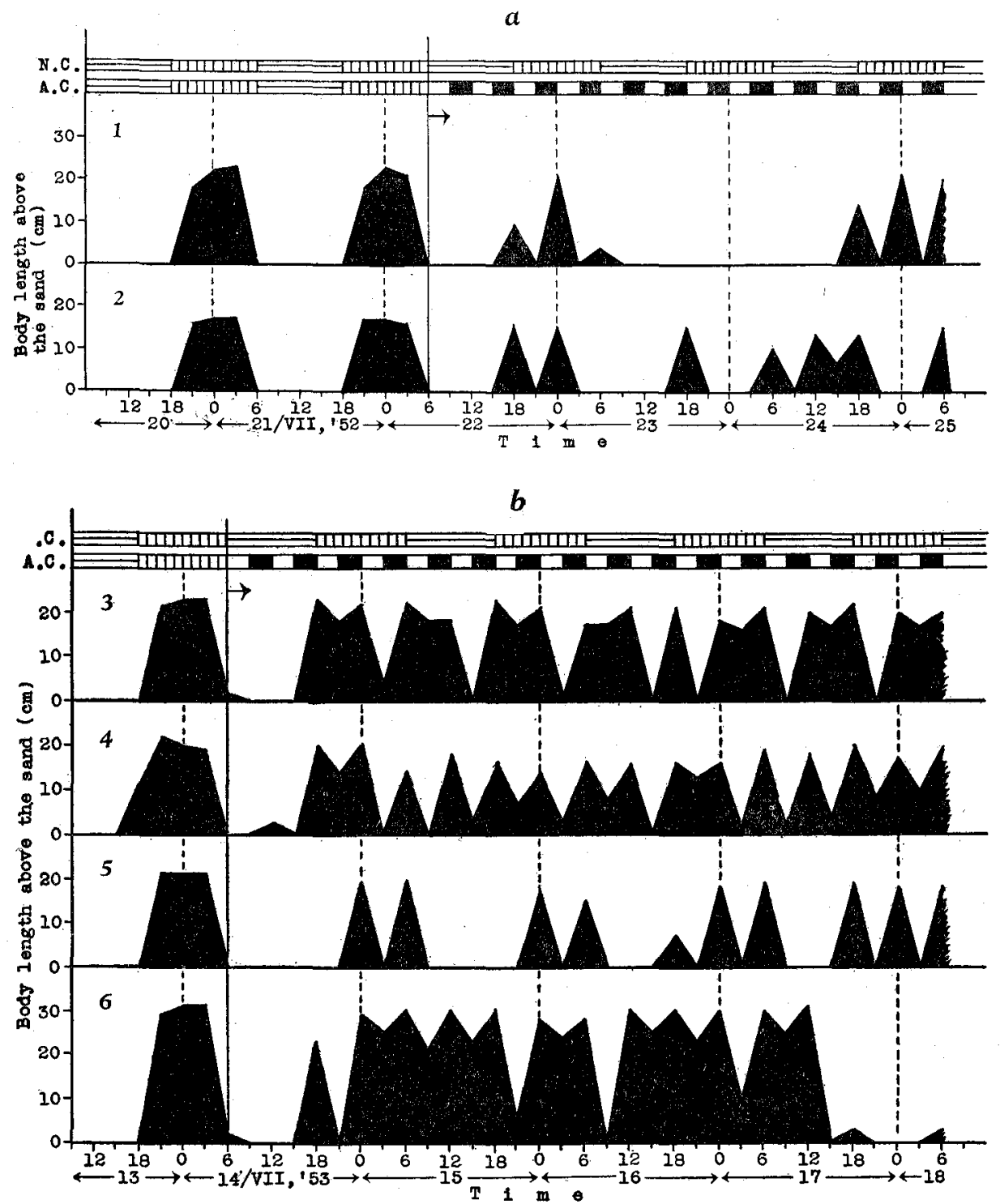

Fig. 3. Features of activity under $3-3$ hours light-dark condition.

$a$ shows the results obtained in 1952 and $b$ shows those obtained in 1953.

words the intrinsic behavior of 24 hours' physiological rhythm is superimposed by the activities caused by the 12 hours' experimental light periodicity. No. 6 becomes irregular, being perfectly disturbed in its rhythmicity.

d) Activities under alternative 1.5 hours illumination and 1.5 hours darkness (one cycle 3 hours)

The experiment was performed during July 25 to 29,1954 , using 4 colonies. 
The intensity of light used was $1000 \mathrm{Lux}$, the water temperature varied between $24.8^{\circ}$ to $27.3^{\circ} \mathrm{C}$. The results are illustrated in Fig. 4.

The activity rhythm of the colony No. 1 is of nearly normal 24 hours cycle. The rhythms of Nos. 2, 3 and 4 become disturbed after 2 days in the experimental environment. Among them, No. 2 is strongly disturbed; Nos. 3 and 4 show somewhat 3 hours cycle. It is clear, whenever, that the intrinsic rhythm and the extrinsic factors are more or less coacting together, thus giving peculiar features to the activity.

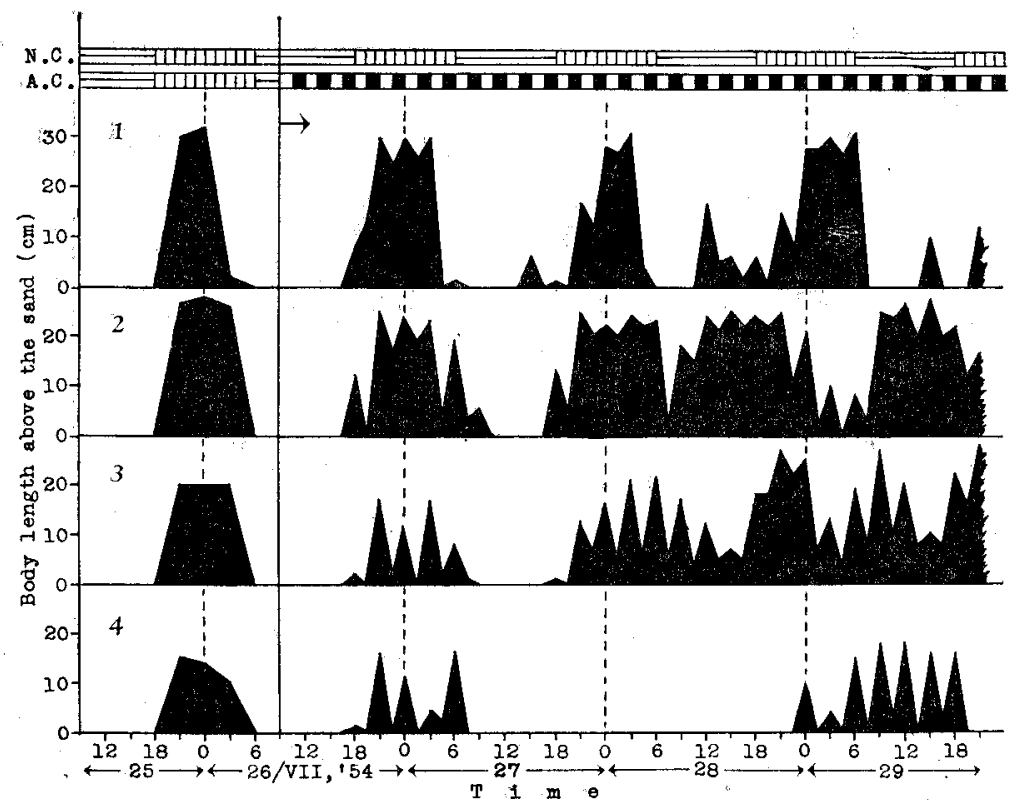

Fig. 4. Features of activity under 1.5-1.5 hours light-dark condition.

e) Activities under alternative 30 minutes illumination and 30 minutes darkness (one cycle 1 hour)

The experiment was performed during July 31 to Aug. 4, 1954, using 4 colonies. The intensity of light used was $1000 \mathrm{Lux}$, the water temperature varied between $25.4^{\circ}$ to $27.4^{\circ} \mathrm{C}$. The results are illustrated in Fig. 5 .

The modes of activities of Nos. 1 and 4 resembled to the normal type. Those of Nos. 2 and 3 are greately disturbed. In this case, the superimposition of the externally originated rhythm upon the intrinsic 24 hours rhythm is not so conspicuous as in the cases of $c$ ) or d). This may be due to the fact that too frequent an alternation of environmental light and darkness is beyond the synchronizing ability of the animal. 


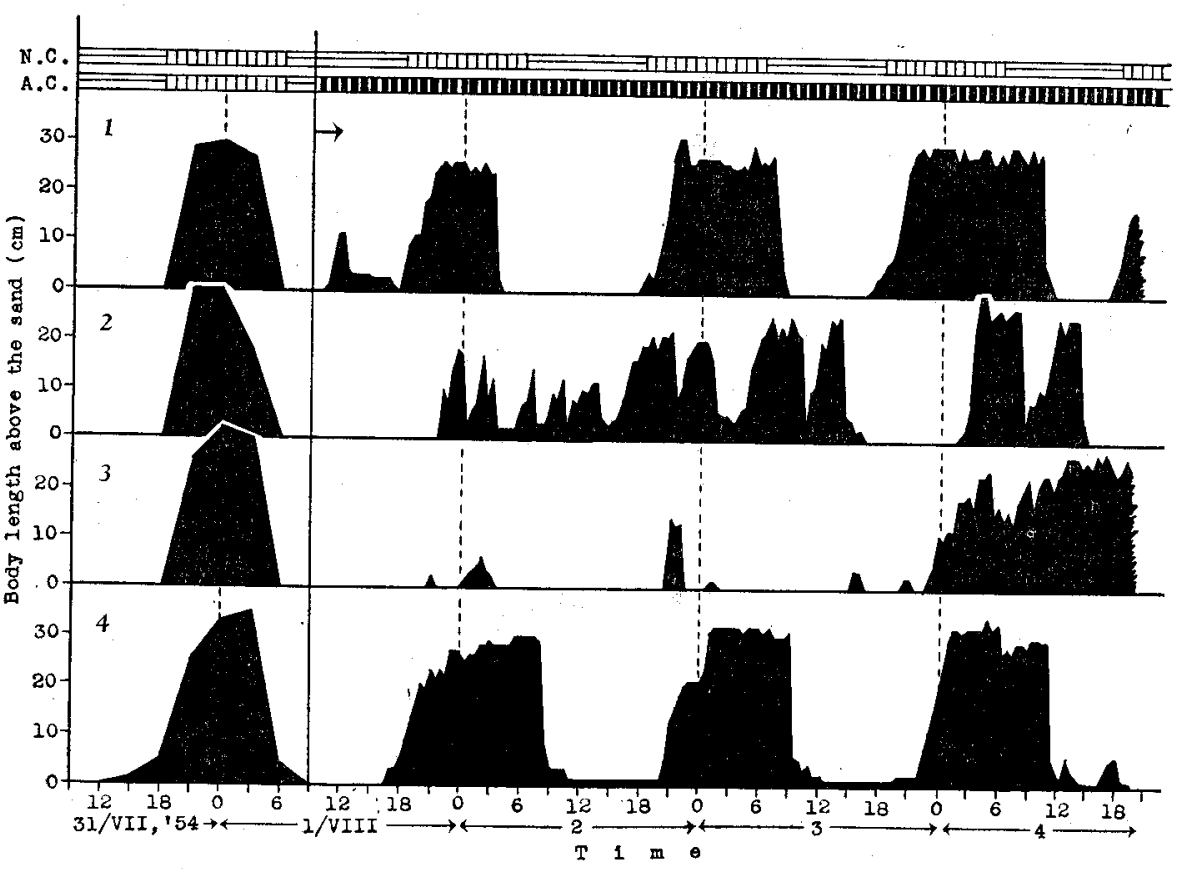

Fig. 5. Features of activity under 30-30 minutes light-dark condition.

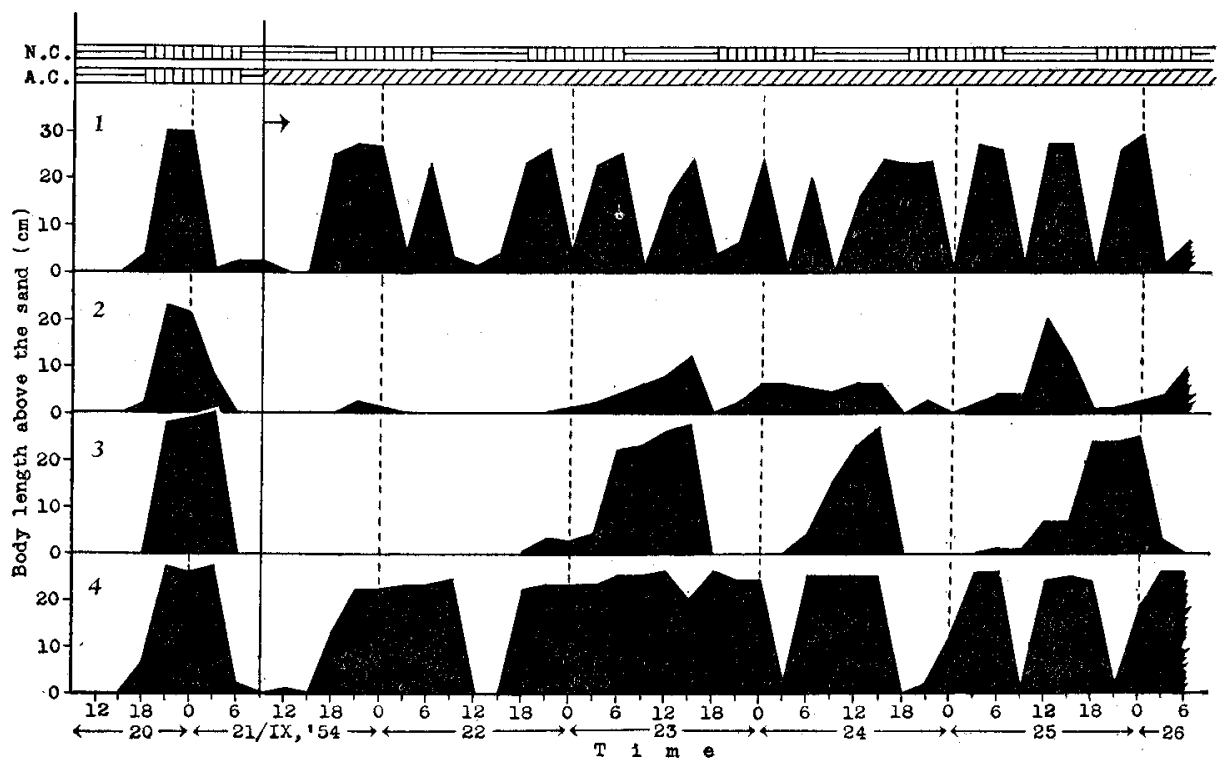

Fig. 6. Features of activity under 15-15 minutes light-dark condition. Period of experiment is indicated by oblique lines in the A.C. column. 
f) Activities under alternative 15 minutes illumination and 15 minutes darkness (one cycle 30 minutes)

The experiment was performed during Sept. 20 to 25 , 1954, using 4 colonies. The intensity of light used was $1200 \mathrm{Lux}$, the water temperature varied between $24.3^{\circ}$ to $27.7^{\circ} \mathrm{C}$. The results are shown in Fig. 6 .

The mode of activity of No. 1 is peculiar, showing somewhat 9 to 12 hours rhythm. Nos. 2 and 3 are irregular, though showing a trace of 24 hours rhythm. No. 4 is perfectly irregular. It must be noted that there is no sign of direct superimposition of the environmental periodic phases upon the behavior rhythm.

g) Activities under alternative 5 minutes illumination and 5 minutes darkness (one cycle 10 minutes)

The experiment was performed during Aug. 28 to Sept. 3, 1955, using 3 colonies. The intensity of light used was $1400 \mathrm{Lux}$, the water temperature varied between $26.7^{\circ}$ to $28.1^{\circ} \mathrm{C}$. The results are illustrated in Fig. 7 .

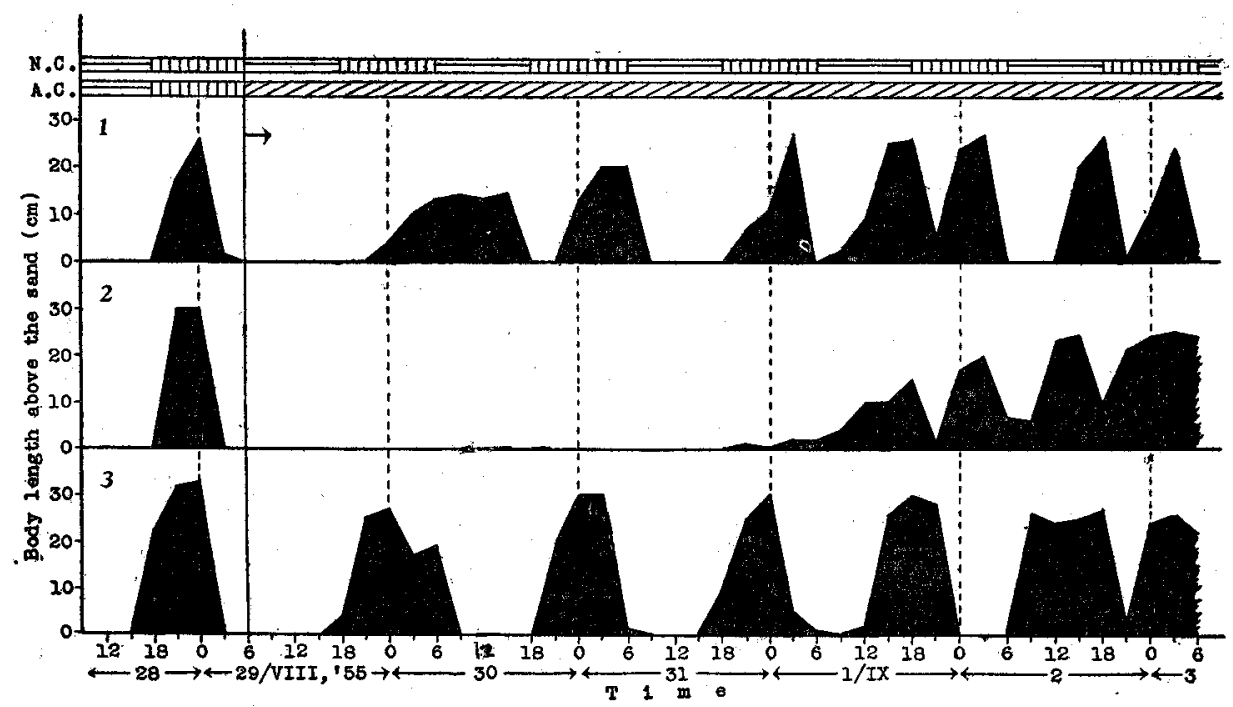

Fig. 7. Features of activity under 5-5 minutes light-dark condition. Period of experiment is indicated by oblique lines in the A.C. column.

No. 1 shows modified 12 hours rhythm. No. 2 is irregular, or having a trace of 12 hours rhythm. No. 3 persists 24 hours rhythm at first, but soon becomes irregular. Thus no colonies show either 24 hours rhythm or environmentally dependent rhythm. They are disturbed or show modified 12 hours rhythm. It is characteristic in this case that the periods, during which the animals contract perfectly beneath the sand, become shorter with the elapse of days, and this phenomenon may be taken as a sign of internal physiological abnormalities. 
As mentioned in the paragraph b), the results of the experiments performed previously led the senior author to suppose that, under extremely shortened cycles of light and darkness the animal disregards the change of light and shows its original normal rhythmic behavior. Such, however, was not the case. The series of the experiments mentioned above indicate somewhat different results. Under extremely shifted rhythmic light conditions, no rule of rhythmicity was found in the behavior of the sea-pen, some being disturbed or made irregular, and others showing some sign of regular behavior but not of 24 hours rhythm. All these facts indicate that, under extremely shifted light conditions, the animal can neither adjust perfectly its internal physiological rhythm to the environmental periodicity, nor behave disregarding perfectly the environmental periodicity. The definite persistence of the original 24 hours rhythm, frequently observed under adequately shifted environments (such as 21-21 hours, 6-6 hours, or 3-3 hours light and dark conditions), may surely be based on the internal physiological rhythm, but we can not give at present any confident answer to the question, why this phenomenon is seen conspicucusly under moderately shifted periodic light conditions and not so clearly under slightly shifted conditions (such as 15-15 hours or 9-9 hours light and dark conditions) or under extremely shifted conditions as mentioned above.

\section{The results of the second series of experiments}

Only one set of experiment was planned, namely, the rhythmic activity under the 21 hours illumination and 3 hours darkness (one cycle 24 hours). The experiment was performed firstly during July 20 to 25,1952 , using 2 colonies, and repeated during July 13 to 18,1953 , using 4 colonies. The intensity of light used was 1470 Lux, the water temperature varied between $26.0^{\circ}$ to $28.5^{\circ} \mathrm{C}$ and $25.0^{\circ}$ to $26.5^{\circ} \mathrm{C}$ respectively. The results are illustrated in Fig. 8.

4 colonies out of 6 seem to persist their original 24 hours rhythm (Nos. 1, 3, 5 and 6), whereas 1 colony seems to bear a feature of 24 hours rhythm (No. 4), and the last 1 colony becomes irregular with the lapse of days (No. 2). Generally speaking, the tendency to persist the original rhythm is noticeable, that is the common characteristic seen in the results of the second series of experiments performed previously. This may be chiefly due to the fact that the sum of the illuminated and darkened hours is 24 hours.

\section{The results of the third series of experiments}

From the experiments mentioned above (1st and 2nd series of experiments), we can see a fair number of colonies persisting their original 24 hours rhythm, in spite of the subjection to abnormal periodic light and dark conditions. However, the periods during which the sea-pens are subjected to the experimental light conditions remain always within 3 to 5 days. Theoretically it is supposed that an animal can continue its perpetual life only when the internal physiological cycles go on in the same place with the environmental cycles. If so, the persisting activities described 

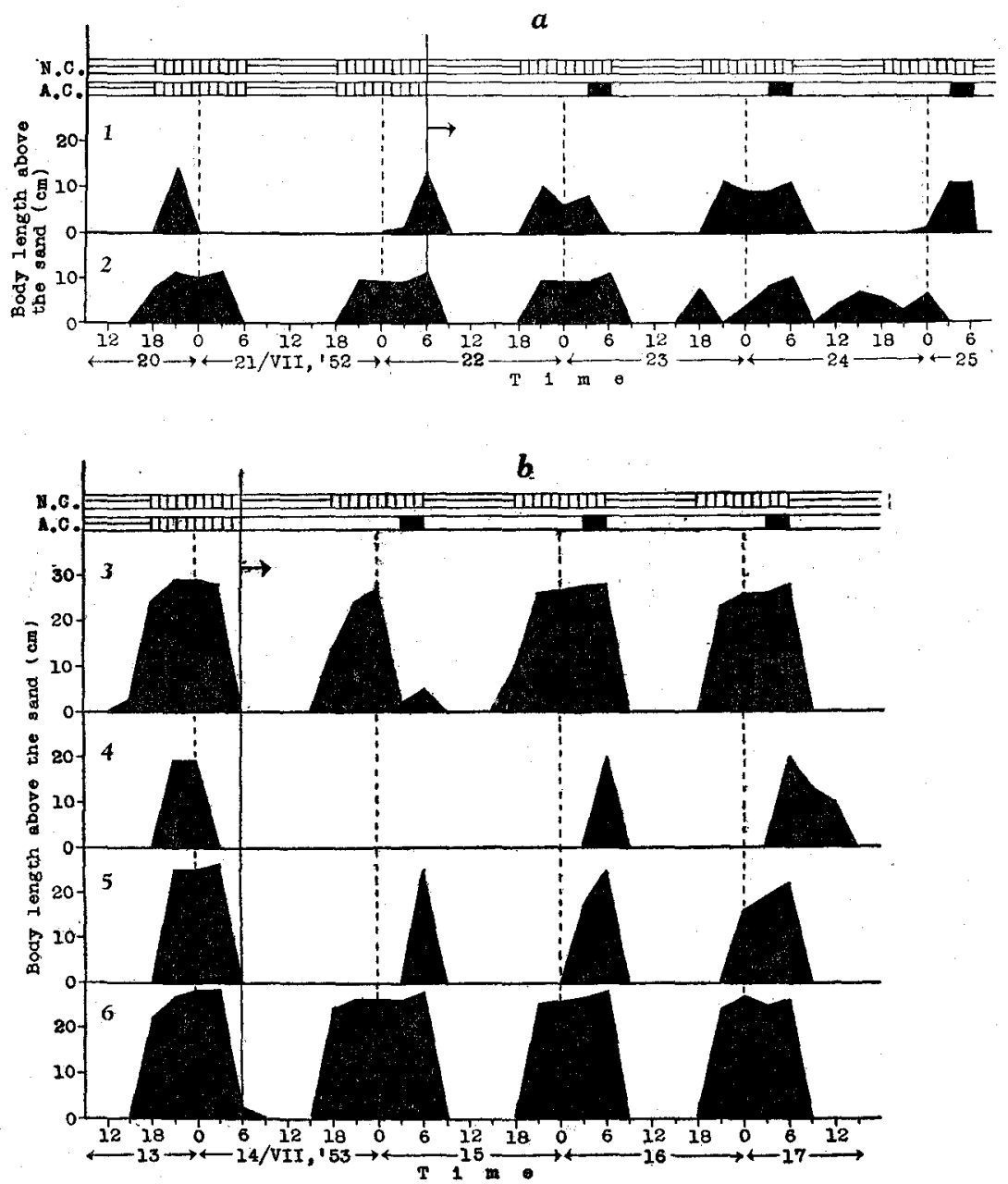

Fig. 8. Features of activity under $21-3$ hours light-dark condition. $a$ shows the results obtained in 1952 and $b$ those obtained in the next year.

above may be due to the short duration of the experiments or may be said as of a false normality, and if we continue to subject them to abnormal light periodicities for longer times, the animals may be thrown into confusion.

From these considerations, we attempted to examine what might happen in the activity when the experimental operation of alternative 30 minutes illumination and 30 minutes darkness were continued for fairly a long time. The experiment was performed during July 17 to 28,1955 , using 4 colonies. The intensity of light used was $1200 \mathrm{Lux}$, the water temperature varied between $26.3^{\circ}$ to $28.6^{\circ} \mathrm{C}$. The results are illustrated in Fig. 9. 


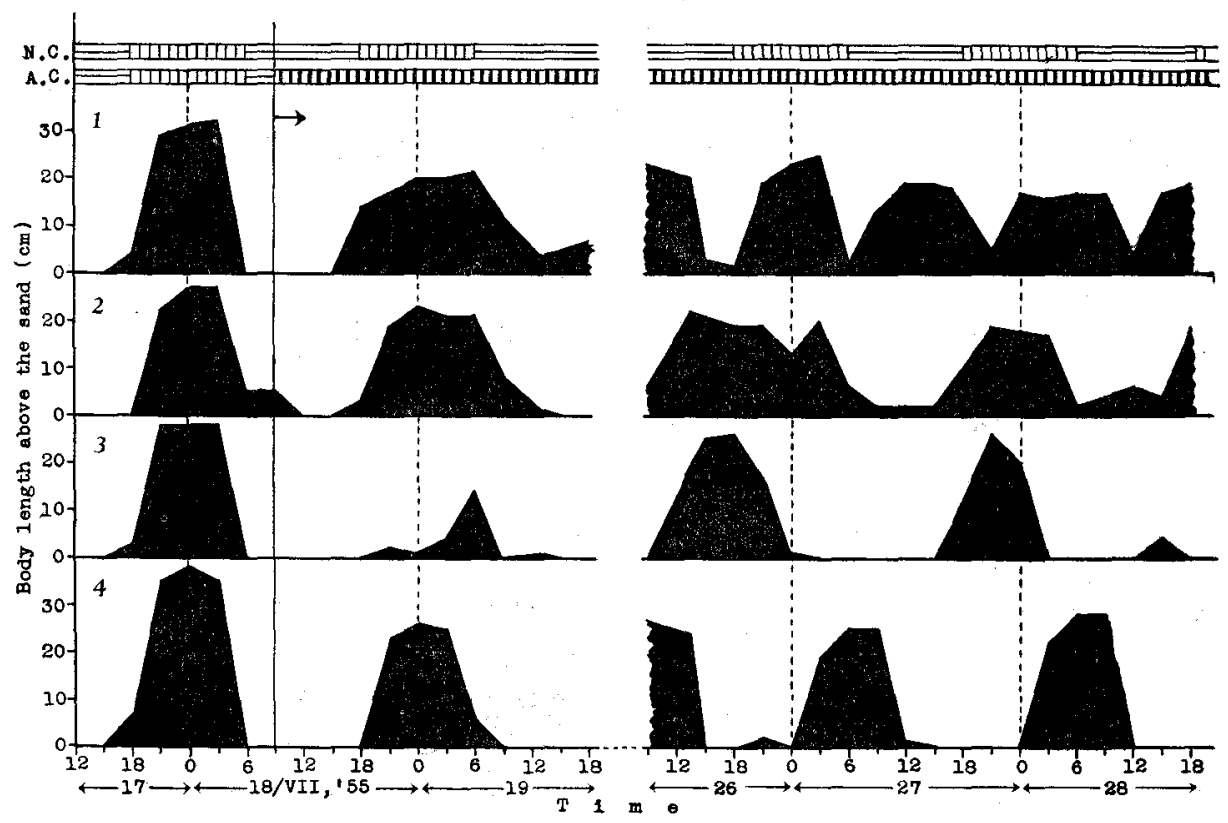

Fig. 9. Features of activity when subjected to 30-30 minutes light-dark condition for 10 days.

It is noted that 2 colonies out of 4 still persist their original 24 hours rhythm (Nos. 2 and 4) after 10 days in the experimental condition. No. 1 shows 12 hours rhythm and No. 327 hours rhythm. After all, the innate persisting nature is so firmly established that it can not be easily disturbed by such a treatment as this. Of course the fact that the influence of environment must not be ignored, is clearly demonstrated by the appearance of the colonies having abnormal rhythmic activities.

\section{Considerations}

1. As has been mentioned in the Introduction, the daily rhythmic activity of Cavernularia is controlled by double factors, namely, the environmental light factor (exogenous factor) and the internal physiological factor (endogenous factor). The senior author has tried since 1943 to clarify the relations existing among these factors and the rhythmic behaviors, and has published several works (see Introduction). This report belongs to the category of works treating the relation between the environmental light factor and the rhythmic behavior.

As the previous works has mostly been published in Japanese, we will summarize them with additions of the present new results (Tables 1,2 and 3). 
Table 1. Rhythmic activities of Cavernularia obesa under alternative light and dark conditions of equal duration.

(Modified from MoRI, 1950, with new data)

\begin{tabular}{|c|c|c|c|c|c|}
\hline \multicolumn{3}{|c|}{ Environmental condition } & \multirow[b]{2}{*}{$\begin{array}{c}\text { Number } \\
\text { of } \\
\text { colonies }\end{array}$} & \multirow[b]{2}{*}{ Date } & \multirow[b]{2}{*}{ Activity } \\
\hline $\begin{array}{c}\text { Periodicity of } \\
\text { light }\end{array}$ & $\left|\begin{array}{c}\text { Illumination } \\
\text { intensity } \\
\text { (Lux) }\end{array}\right|$ & $\begin{array}{l}\text { Range of } \\
\text { water } \\
\text { temperature } \\
\left({ }^{\circ} \mathrm{C}\right)\end{array}$ & & & \\
\hline $\begin{array}{l}24-24 \text { periodic- } \\
\text { ity (alternative } \\
24 \text { hours illumi- } \\
\text { nation and } 24 \\
\text { hours dark- } \\
\text { ness; one cycle } \\
48 \text { hours) }\end{array}$ & 1400 & $26.7 \sim 28.1$ & 3 & $\begin{array}{l}\text { Aug. } 28 \\
\text { Sept. } 3 \\
(1955)\end{array}$ & $\begin{array}{l}\text { Synchronization of rhythmic ac- } \\
\text { tivity to light-dark cycle is } \\
\text { generally imperfect. ( } 1 \text { shows } \\
\text { modified } 48 \text { hours, } 1 \text { shows modi- } \\
\text { fied } 24 \text { hours, and the other } \\
\text { shows irregular rhythm) }\end{array}$ \\
\hline $\begin{array}{l}21-21 \text { periodic- } \\
\text { ity (one cycle } \\
42 \text { hours) }\end{array}$ & 1400 & $24.3 \sim 27.7$ & 4 & $\mid \begin{array}{c}\text { Sept. } 20 \\
\widetilde{2} 26 \\
(1954)\end{array}$ & $\begin{array}{l}\text { Synchronization generally imper- } \\
\text { fect and some shows tendency to } \\
\text { persist } 24 \text { hours rhythm. ( } 2 \text { are } \\
\text { irregular or show rather modi- } \\
\text { fied } 42 \text { hours rhythm; } 1 \text { quite } \\
\text { irregular; the other shows strong } \\
\text { persistency to } 24 \text { hours rhythm) }\end{array}$ \\
\hline $\begin{array}{l}18-18 \text { periodi- } \\
\text { city (one cycle } \\
36 \text { hours) }\end{array}$ & 1230 & $27.2 \sim 29.4$ & 4 & $\underset{(\widetilde{1943})}{\widetilde{S e p t .} 7}$ & $\begin{array}{l}\text { Synchronization generally imper- } \\
\text { fect. ( } 1 \text { is synchronized; the } \\
\text { other } 3 \text { show two active phases } \\
\text { during a dark period) }\end{array}$ \\
\hline $\begin{array}{l}15-15 \text { periodic- } \\
\text { ity (one cycle } \\
30 \text { hours) }\end{array}$ & 1230 & $26.0 \sim 28.8$ & 4 & $\begin{array}{r}\text { Aug. } 5 \\
\widetilde{1} \\
(1943)\end{array}$ & $\begin{array}{l}\text { Synchronization generally per- } \\
\text { fect. }\end{array}$ \\
\hline $\begin{array}{l}9-9 \text { periodic- } \\
\text { ity (one cycle } \\
18 \text { hours) }\end{array}$ & 1050 & $27.6 \sim 29.4$ & 4 & $\begin{array}{r}\text { Sept. } 5 \\
(1942) \\
(13)\end{array}$ & $\begin{array}{l}\text { Synchronization generally per- } \\
\text { fect. }\end{array}$ \\
\hline $\begin{array}{l}6-6 \text { periodic- } \\
\text { ity (one cycle } \\
12 \text { hours) }\end{array}$ & 1050 & $19.6 \sim 22.9$ & 4 & $\begin{array}{r}\text { Oct. } 12 \\
(1942) \\
(19\end{array}$ & $\begin{array}{l}2 \text { colonies show modified } 12 \\
\text { hours rhythm, the rest } 2 \text { show } \\
\text { tendency of persisting } 24 \text { hours } \\
\text { rhythm. }\end{array}$ \\
\hline \multirow{2}{*}{$\begin{array}{l}3-3 \text { periodic- } \\
\text { ity (one cycle } \\
6 \text { hours) }\end{array}$} & 1470 & $26.0 \sim 28.5$ & 2 & $\begin{array}{r}\text { July } 20 \\
\sim 225 \\
(1952)\end{array}$ & \multirow{2}{*}{$\begin{array}{l}\text { Synchronization generally imper- } \\
\text { fect. ( } 1 \text { synchronized, } 1 \text { shows } \\
12 \text { hours rhythm, } 2 \text { show } 24 \\
\text { hours rhythm, and the rest } 2 \text { are } \\
\text { irregular. In all cases, super- } \\
\text { imposition of environmental } \\
\text { periodicity upon endogenous } \\
\text { rhythm is conspicuous) }\end{array}$} \\
\hline & 1470 & $25: 0 \sim 26.6$ & 4 & $\begin{array}{c}\text { July } 13 \\
\sim 18 \\
(1953)\end{array}$ & \\
\hline $\begin{array}{l}11 / 2-11 / 2 \text { perio- } \\
\text { dicity (one cy- } \\
\text { cle } 3 \text { hours) }\end{array}$ & 1000 & $24.8 \sim 27.3$ & 4 & $\begin{array}{c}\text { July } 25 \\
\widetilde{1} 29 \\
(1954)\end{array}$ & $\begin{array}{l}\text { Synchronization generally imper- } \\
\text { fect. (Intrinsic behavior is al- } \\
\text { ways intensely superimposed by } \\
\text { extrinsic periodicity; } 1 \text { shows } \\
\text { tendency of persisting } 24 \text { hours } \\
\text { rhythm, others are disturbed) }\end{array}$ \\
\hline $\begin{array}{l}1 / 2-1 / 2 \text { periodic- } \\
\text { ity (one cycle } \\
1 \text { hour) }\end{array}$ & 1000 & $25.4-27.4$ & 4 & $\begin{array}{l}\text { July } 31 \\
\text { Aug. } 4 \\
(1954)\end{array}$ & $\begin{array}{l}\text { Synchronization generally impos- } \\
\text { sible. ( } 2 \text { showing } 24 \text { hours rhy- } \\
\text { thm, others are disturbed; } \\
\text { superimposition is imperfect) }\end{array}$ \\
\hline $\begin{array}{l}1 / 4-1 / 4 \text { periodic- } \\
\text { ity (one cycle } \\
30 \text { minutes) }\end{array}$ & 1200 & $24.3 \sim 27.7$ & 4 & $\left|\begin{array}{r}\text { Sept. } 20 \\
25 \\
(1954)\end{array}\right|$ & $\begin{array}{l}\text { Synchronization perfectly impos- } \\
\text { sible. ( } 1 \text { shows } 9-12 \text { hours rhy- } \\
\text { thm, } 1 \text { is irregular, and the } \\
\text { other } 2 \text { shows trace of } 24 \text { hours } \\
\text { rhythm) }\end{array}$ \\
\hline $\begin{array}{l}1 / 12^{-1 / 12} \text { perio- } \\
\text { dicity (one cy- } \\
\text { cle } 10 \text { minutes) }\end{array}$ & 1400 & $26.7 \sim 28.1$ & 3 & \begin{tabular}{|} 
Aug. 28 \\
Sept. 3 \\
$(1955)$
\end{tabular} & $\begin{array}{l}\text { Synchronization perfectly impos- } \\
\text { sible. ( } 1 \text { persists } 24 \text { hours rhy- } \\
\text { thm, } 1 \text { irregular, and the rest } \\
1 \text { shows somewhat } 12 \text { hours } \\
\text { rhythm) }\end{array}$ \\
\hline
\end{tabular}


Table 2. Rhythmic activities of Cavernularia obesa under alternative light and dark condition of different duration, one cycle of which was 24 hours.

(Modified from MORI, 1950, with new data)

\begin{tabular}{|c|c|c|c|c|c|}
\hline \multicolumn{3}{|c|}{ Environmental condition } & \multirow[b]{2}{*}{$\begin{array}{c}\text { Number } \\
\text { of } \\
\text { colonies }\end{array}$} & \multirow[b]{2}{*}{ Date } & \multirow[b]{2}{*}{ Activity } \\
\hline $\begin{array}{l}\text { Periodicity } \\
\text { of } \\
\text { light }\end{array}$ & $\begin{array}{c}\text { Illumination } \\
\text { intensity } \\
\text { (Lux) }\end{array}$ & $\begin{array}{l}\text { Range of } \\
\text { water tem- } \\
\text { perature } \\
\left({ }^{\circ} \mathrm{C}\right)\end{array}$ & & & \\
\hline \multirow{2}{*}{$\begin{array}{l}\text { periodic- } \\
\text { (alterna- } \\
21 \text { hours } \\
\text { and } 3 \\
\text { dark- }\end{array}$} & 1470 & $26.0 \sim 28.5$ & 2 & \begin{tabular}{|} 
July 20 \\
$\sim 25$ \\
$(\mathbf{1 9 5 2})$
\end{tabular} & \multirow{2}{*}{$\begin{array}{l}\text { Synchronization } \\
\text { (Generally persist original } 24 \\
\text { hours rhythm; } 1 \text { becomes ir- } \\
\text { regular) }\end{array}$} \\
\hline & 1470 & $25.0-26.5$ & 4 & $\begin{array}{c}\text { July } 13 \\
\sim \widetilde{1953}\end{array}$ & \\
\hline $\begin{array}{l}18-6 \text { periodic- } \\
\text { ity }\end{array}$ & 1200 & $19.0 \sim 22.2$ & 4 & $\begin{array}{l}\text { Oct. } 27 \\
\text { Nov. } 5 \\
(1944)\end{array}$ & $\begin{array}{l}\text { Synchronization generally impos- } \\
\text { sible. ( } 1 \text { is imperfectly synchro- } \\
\text { nized; others are more or less } \\
\text { disturbed, though showing deep- } \\
\text { ly rooted tendency of persisting } \\
\text { original day-night rhythm) }\end{array}$ \\
\hline $\begin{array}{l}15-9 \text { periodic- } \\
\text { ity }\end{array}$ & 1700 & $26.5 \sim 29.0$ & 4 & $\begin{array}{r}\text { Aug. } 4 \\
(1944)\end{array}$ & Synchronization perfect. \\
\hline $\begin{array}{l}9-15 \text { periodic. } \\
\text { ity }\end{array}$ & 1200 & $19.7 \sim 21.0$ & 5 & $\begin{array}{r}\text { Nov. } 1 \\
\underset{(1944)}{5}\end{array}$ & Synchronization perfect. \\
\hline $\begin{array}{l}6-18 \text { periodic- } \\
\text { ity }\end{array}$ & 1200 & $27.0-29.0$ & 3 & $\begin{array}{r}\text { Aug. } 23 \\
(\mathbf{1 9 4 6 )}\end{array}$ & $\begin{array}{l}\text { Synchronization somewhat imper- } \\
\text { fect. (Colonies do not stay in } \\
\text { expanded condition through } \\
\text { whole period of darkness but } \\
\text { contract in the course, and it } \\
\text { may safely be said that general } \\
\text { features of activity resemble the } \\
\text { normal rhythmic activity; some } \\
\text { show irregular activity occasion- } \\
\text { ally) }\end{array}$ \\
\hline $\begin{array}{l}3-21 \text { periodic- } \\
\text { ity }\end{array}$ & 1200 & $21.1 \sim 23.5$ & 3 & $\begin{array}{l}\text { Oct. } 12 \\
\sim 18 \\
(1946)\end{array}$ & $\begin{array}{l}\text { General features are similar to } \\
6-18 \text { periodicity. }\end{array}$ \\
\hline
\end{tabular}

Table 3. Reversal of activity rhythm of Cavernularia obesa by alternative 12 hours light of various illumination intensity and 12 hours darkness.

(Modified from MorI, 1950)

\begin{tabular}{|c|c|c|c|c|}
\hline \multicolumn{2}{|c|}{ Environmental condition } & \multirow{2}{*}{$\begin{array}{l}\text { Number } \\
\text { of } \\
\text { colonies }\end{array}$} & \multirow[b]{2}{*}{ Date } & \multirow[b]{2}{*}{ Activity } \\
\hline $\begin{array}{l}\text { Illumination } \\
\text { intensity } \\
\text { (Lux) }\end{array}$ & $\begin{array}{c}\text { Range of water } \\
\text { temperature } \\
\left({ }^{\circ} \mathrm{C}\right)\end{array}$ & & & \\
\hline 1230 & $27.6-29.5$ & 4 & $\mid \begin{array}{c}\text { Sept. } 5-13 \\
(1942)\end{array}$ & Reversal completes within 2 days. \\
\hline 130 & $19.6-22.9$ & 4 & $\begin{array}{c}\text { Oct. } 12-19 \\
(1942)\end{array}$ & Reversal completes within 2 days. \\
\hline 7 & $19.3-24.2$ & 4 & $\begin{array}{c}\text { Oct. } 17-24 \\
(1943)\end{array}$ & Reversal completes within 2.5 days. \\
\hline 1.2 & $26.3-29.0$ & 5 & Aug. $4-11$ & $\begin{array}{l}\text { Reversal completes generally within } 6 \\
\text { days, but } 1 \text { colony persists original nor- } \\
\text { mal rhythm. }\end{array}$ \\
\hline 0.3 & $26.5-28.2$ & 4 & $\begin{array}{c}\text { Aug. } 23-31 \\
(1944)\end{array}$ & $\begin{array}{l}2 \text { colonies reverse their activity phase } \\
\text { within } 7 \text { days; } 1 \text { shows rhythm of } 15 \\
\text { hours quiescence and } 21 \text { hours activity, } \\
\text { and the other is irregular. }\end{array}$ \\
\hline
\end{tabular}


Various data cited in Tables 1 and 2 may be schematically represented as Fig. 10.

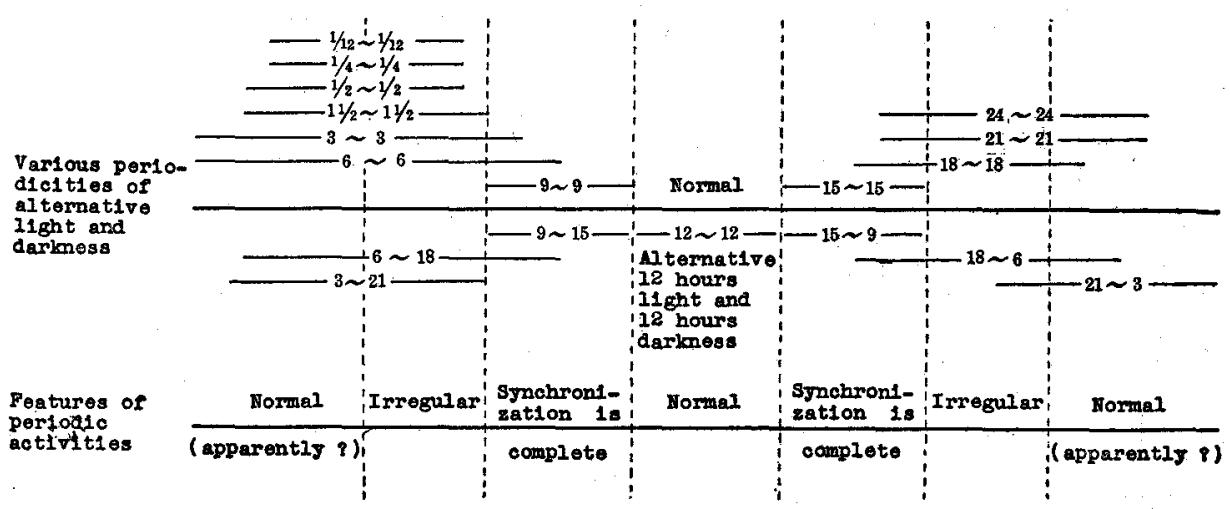

Fig. 10. Features of activities, with variable ranges, exhibited under various periodicities of environmental light and darkness, summarized from Tables 1 and 2 .

Some interesting points may be seen in these Tables and Figure.

A. Firstly, when the lengths of alternative light and dark periods are made equal with each other, features of rhythmic activities become different as the lengths of light-dark cycles vary. The perfect synchronization may occur only when one cycle is restricted within the range of 18 to 30 hours, and if the length of a cycle outsteps beyond this range, irrespective of longer or shorter side, the synchronization becomes gradually imperfect, and some animals even show normal (at least apparently) rhythmic behavior. This tendency of exhibiting the normal rhythm is seen most obviously under alternative 6-6 or 3-3 hours environmental periodicities; but as a cycle becomes shorter, activity of most animals shows irregular or particular rhythms (such as 9 or 12 hours cycles). The circumstance is somewhat different at a longer environmental cycle. Although, in this case also a few colonies persist the normal day-night rhythm, general features are somewhat different in comparison with those under a shorter environmental cycle. Most colonies behave irregularly or exhibit particular rhythms, though manifesting an intense tendency of persisting the normal rhythm.

We can find some papers which treat rhythmic activity under shortened or lengthened environmental light cycles than the normal day-night cycle. Hartman (1932), using a rhesus monkey Macacus rhesus, whose chief activity could be seen in the forenoon, established 12 hours rhythm by alternating 6 hours light period and 6 hours dark period (from Calhoun, 1946). According to Kalabuchov (1940), it took a transition period of about 10 days to induce a monkey to sleep in the 6 hours dark period and to be active in the 6 hours light period (from CALHoun, 1946). HEMMINGREN and KRARUP (1937) attempted to establish in a white rat a 16-hoursday in which an 8 hours dark period alternated with an 8 hours light period. 
Concerning 3 adult females under this light regimen, they said that "even after two months, a struggle was still going on between the tendency to display the activity in the dark period and the tendency to have one pronounced period of activity once every 24 hours" (from CALHoun, 1946). Browman (1943) also attempted to establish a 16 hours rhythm in a white rat aged 40 days. 2 females and 1 male each that had been born and raised in (a) constant light, (b) constant darkness, and (c) normal day-night conditions, were used. The parents of these rats had been subjected respectively to these conditions for 60 days before the birth of the young. All young which had been raised to day 40 in constant light adapted to 16 hours day. When they were raised under constant darkness, 1 out of 3 adapted 16 hours day, the other 2 retained 24 hours rhythm (although from time to time they showed 16 hours rhythm). The rats raised under normal conditions developed 24 hours rhythm, though at times showed 16 hours rhythm (from CalHoun, 1946).

The prairie meadow mouse, Microtus ochrogaster, was subjected, by CALHoun (1945), to consecutive 7 light-darkness cycles consisting of 24 hours of darkness followed by 24 hours of light ( $25 \mathrm{ft} . \mathrm{c}$ ). Upon analysis of the results, it was found that both 24 hours and 48 hours rhythms of activity were in operation. The 24 hours rhythm was definitely superimposed upon the altered activity rhythm under the 48 hours "day".

As for the physiological rhythm, KLeitman and Kleitman (1953) stated that the pulsation rhythm of a man was made adapted more easily to 18 hours cycle than the temperature rhythm (from Aschoff, 1955).

Recently, German investigator TRIBUKaIT (1954) had subjected the mouse to various lengths of light-dark cycles--viz. 23 hours cycle (alternative 11.5 hours light and 11.5 hours dark), 22 hours cycle, 21 hours cycle, 20 hours cycle and 19 hours cycle. This animal had two activity peaks during a night, the primary one occurring just after the sunset and the secondary one just before the sunrise. This normal mode of activity was observed under longer cycles than 22 hours periodicity; but the time of the primary activity shifted gradually towards the secondary peak as the length of a cycle was shortened, uniting at last into one. This state could be observed at 21 hours light-dark periodicity, and in a shorter period than this the activity was disturbed (e.g. at 20 hours periodicity). Under a much shorter "day", the rhythmic activity reappeared, but in this case the rhythm was "normal", i.e., 24 hours "day". Tribukait considered that the secondary peak was dependent directly on the environment, whereas the primary peak was endogenous. It must be noticed that under modified environment, the endogenous one disappears firstly, and again reappears under intensely modified conditions. This conclusion recalls us the results of activities of our sea-pens. When a "day" was shortened, the sea-pen was at first synchronized with the environmental periodicity, but as the modification of the environment became greater, the irregularity of activity grew larger, and the number of colonies persisting normal 24 hours rhythm became larger. In this animal, however, under extraordinary 
shifted conditions, the persistency of 24 hours rhythm became again weakened.

YAMAZAKI (1955) studied recently the egg laying activity of a moth, Antheraea pernyi, which deposited eggs at night in nature. When subjected to the alternative 1 hour light (100 Lux) and 1 hour darkness, it layed eggs only in the dark, but when subjected to the alternative 10 minutes light and 10 minutes darkness, the rhythm was disturbed and the egg-laying behavior was ceased. Though the alternative periodicity is shorter in this experiment, the general feature has some resemblance to the case of the sea-pen.

$B$. Secondly; when the relative length of light and dark hours are changed, maintaining the total length as 24 hours, modes of activity change according to the different length of light hours. When it is shorter than 12 hours, the synchronized rhythmic activity can easily be established, though the sea-pen does not expand throughout the dark period. In other words, the sub-normal activity is exhibited under these circumstances. On the contrary, when the light hours are lengthened, the synchronization becomes difficult gradually, irregularity in behavior getting markedly, and at last the endogenic rhythm gains more and more its force.

Now let us see the literature. Aschoff and Meyer-Lohmann (1955a, b) published the works concerning this category of experiment. They employed some rodents (mouse and rat) and a passerine bird (Chloris chloris). By subjecting mice to alternative 6 hours light (300 Lux) and 18 hours dark cycle or 18 hours light and 6 hours dark cycle, the conspicuous endogeneity was demonstrated. As above mentioned, this animal shows two activity maxima during night, the interval of which is about 15.5 hours in the ordinary "day". In the experimental "day", in which the length of light hours was shortened or lengthened by 6 hours, the interval of rest was shortened or lengthened by about 1.5 hours only. They also measured the amount of activity, and found that it reached a maximum when lighted hours were 14 to 16 hours per day, and in cases of longer or shorter lighted hours than these the amount was decreased. In the passerine bird, they changed the lighted hours (300 Lux) per day as $10,8,6$ or 4 hours respectively, and measured the amount of activity. The highest activity per light hours and the highest total activity per 24 hours was found respectively under 8 lighted hours per day and 12 lighted hours per day. This bird showed two activity peaks during daytime, the prime maximum in the morning and the ancillary maximum in the evening. Although the both maxima had the endogenous component of rhythmicity, only the prime maximum was the inalienable constituent. The ancillary maximum fluctuated individually or from day to day, and was more determined by clues. The time displacement of the maxima to each other was limited.

After all, we have an opinion that, as the environmental light-dark periodicity shifts from the normal day-night cycle, the activity rhythm at first synchronized with the changed environmental periodicity, but the original endogenous rhythm gradually gains its power, and at last under extraordinary conditions disturbance of the rhythm 
becomes conspicuous. Of course, the absolute length of light and dark hours that causes various modifications in the activity rhythm differs with the applied intensity of illumination.

C. Thirdly, the influence of illumination intensity on the reversal of rhythm shall be considered. It will be natural that, stronger the intensity, easier the accomplishment of the reversal. By the way, it must be noticed that even so feeble a light such as 0.3 Lux may reverse the rhythm. Brown, Fingerman and Hines (1954) studied the mechanism of reversal of daily rhythm in color change of the fiddler crab, Uca pugnax, by illumination by night and darkness by day. The animals were subjected to a series of combination of illumination by night (197 o'clock) and dimmer illumination by day (7-19 o'clock). Some of their results are as follows. When illuminated by $100 \mathrm{ft}$. c. by night and kept in total darkness by day, complete reversal was observed. When illuminated by $25 \mathrm{ft}$. c. by night and by $2 \mathrm{ft}$. c. by day, shift of phase by about 6 hours was observed after 5 days of exposure. Whereas when illuminated by $50 \mathrm{ft}$. c. by day, no change in the phase was observable. They concluded that, "a graded series of amount of shift was obtained which was capable of being interpreted in terms of two operating factors: (a) the strength of the stimulus in the form of the dark to light change, and (b) the absolute brightness of the higher illumination." Although this work is concerned with the physiological rhythm, we think that the conclusion may be applicable to the behavior rhythm. Indeed, Mori (1945a) has already pointed out that both absolute values of environmental factors and grades of shifting (or relative values) of these factors must be taken into consideration in the analysis of daily rhythmic activity in general.

2. As has been mentioned, the behavior rhythm of an animal is strongly influenced by the periodicity of environmental factors, but it is also true that another base for the behavior rhythms is given by the internal physiological rhythm. From this point of view the senior author and/or his colleague have been making effort to clarify the metabolic processes taking place in the course of a day (refer to MoRI, 1944a and c, 1950; TAKADA and MORI, 1956, 1957). In this report, however, we will not discuss about these metabolic rhythms, but we will note here that investigators of this sort of phenomena should not ignore this point.

\section{Summary}

1. The sea-pen, Cavernularia obesa, has on one hand, a marked tendency to persist its normal daily rhythm of activity under shifted light conditions, but on the other hand the light influences considerably its mode of activity. This report concerns with the modifications of the activity under various abnormal day-night cycles. The illumination intensity used in the experiments ranged between 1000-1700 Lux (mostly about 1200 Lux).

2. When the alternative light and dark periods of equal lengths are applied, 
features of the rhythmic activity differ with the lengths of the environmental lightdark cycles. The perfect synchronization is seen only when a cycle of the environmental light periodicity is restricted within 18 to 30 hours, and if the period of a cycle is beyond these ranges, irrespectively longer or shorter, the synchronization becomes gradually imperfect, and some animals even show "normal" (at least apparently) rhythmic behavior. This tendency is seen most obviously under alternative 6-6 or 3-3 hours environmental periodicities, and as a cycle becomes shorter, the activity of most animals falls into an irregular or a particular rhythm (such as 9 or 12 hours rhythms). The circumstances are somewhat different at a longer environmental cycle. Although, in this case too, some colonies persist their normal day-night rhythm, the feature is rather different in comparison with that under a shorter environmental cycle. Most colonies become irregular or exhibit particular rhythms, though manifesting a strong tendency of persisting the normal rhythm.

3. When the relative length of light and dark hours is changed, maintaining the total length as 24 hours, modes of activity become different according to the light hours are lengthened or shortened. When they are shortened than 12 hours, the synchronized rhythmic activity can easily be established, though the sea-pen does not expand through all the time of dark period. Viewing from a different point, it can be said that the sub-normal activity is exhibited under these circumstances. On the contrary, when the light hours are lengthened, the synchronization becomes difficult, irregularity getting conspicuous, and the endogeneity gains more and more its force.

4. Some literature were considered comparing with our results.

5. It was pointed out that in the study of daily rhythmic activity we must recognize the importance of the approach from two sides, one from the environmental control and the other from the internal physiological control.

\section{LITERATURES CITED}

Aschoff, J. 1954. Zeitgeber der tierischen Tagesperiodik. Naturwiss., 41, 49-56.

- 1955. Exogene und endogene Komponente der 24 Stunden-Periodik bei Tier und Mensch. Naturwiss., 21, 569-575.

\& Meyer-LohmanN, J. 1955a. Die Aktivitätsperiodik von Nagern im künstlichen 24-Stunden-Tag mit 6-20 Stunden Lichtzeit. Z. vergl. Physiol., 37, 107-117. $\&$ 1955b. Die Aktivität gekäfigter Grünfinken im 24-StundenTag bei unterschiedlich langer Lichtzeit mit und ohne Dämmerung. Z. Tierpsychol,, 12, 254-265.

Browman, L. G. 1943. The effect of bilateral optic enucleation upon the activity rhythms of the albino rat. J. Comp. Psychol., 36, 33-46.

Brown, F. A., Jr., Fingerman, M. and Hines, M. N. 1954. A study of the mechanism involved in shifting of the phases of the endogenous daily rhythm by light stimuli. Biol. Bull., 106, 308-317.

Calnoun, J. B. 1944-1946. Twenty-four hour periodicities in the animal kingdom. J. Tennessee Academy of Sci., 19-20.

1945. Diel activity rhythms of the rodents, Microtus ochrogaster and Sigmodon

hispidus hispidus. Ecol., 26, 251-273. 
Hartman, C. G. 1932. Studies in the reproduction of the monkey, Macacus (Pithecus) rhesus, with special reference to menstruation and pregnancy. Carnegie Institution Wash., Contributions to Embryology, 23, 1-162.

HemMingsen, A. M. and KRARUP, N. B. 1937. Rhythmic diurnal variation in the oestrous phenomena of the rat and their susceptibility to light and dark. Biol. Meddel. Kobenh., 13, 1-64.

Kalabuchov, H. N. 1940. The study of the 24-hour cycle of activity of animals. Uspekhi Sovrennoi Biologii, 12, 1-24.

Kleitman, N. 1949. Biological rhythms and cycles. Physiol. Rev., 29, 1-30.

MORI, S. 1945a. General considerations on the relations between behavior rhythms of animals and periodicities of their environmental factors. Kyodai Seiri Seitai, 39. (in Japanese)

1947a. A concept on mechanisms of the endogenous daily rhythmic activity. Mem. Coll. Sci., Univ. Kyoto, Ser. B, 19, 1-4.

1948a. Harmony between behavior rhythm and environmental rhythm. Ibid., 71-74.

1948b. Rhythmic activities of animals. Hoppô Syuppan Sya. Sapporo. (in Japanese)

1943a. Daily rhythmic activity of the sea-pen, Cavernularia obesa Valenciennes. I.

Observations in nature. Zool. Mag., 55, 285-291. (in Japanese)

1943b. do. II. Activities under constant darkness and constant illumination. Ibid., $55,247-253$. (in Japanese)

1944a. do. III. Controlling of the activity by light. Ibid., 56, 81-85. (in Japanese)

1944b. do. IV. Observations of the activity in winter. Ibid., 56, 86-90. (in Japanese)

1944c. do. V. Activities under constant illumination and constant darkness in winter

and influence of water temperature. Ibid., 56, 91-95. (in Japanese)

1944d. do. VI. Analysis of the endogenous rhythm. (1). Ibid., 56, 96-100. (in Japanese)

1944e. do. VII. Change of reaction to light through a night. Ibid., 56, 101-104. (in

Japanese)

1945b. do. VIII. Endogenous daily rhythmic activity. Kyodai Seiri Seitai., 19. (in Japanese)

- 1947b. do. IX. Activities when kept long under constant darkness. Physiol. and

Ecol., 1, 8-14. (in Japanese with English résumé)

1949. do. XI. Controlling of the activity by light (2). Ibid., 3, 32-37. (in Japanese

with English résumé)

1950. do. XII. Conclusions-Problems on relations among environments, behaviors and internal physiological conditions. Ibid., 4, 12-20. (in Japanese with English résumé)

PARK, O. 1940. Nocturnalism-The development of a problem. Ecol. Monogr., 10, 485-539.

TAKADA, N. \& MoRI, S. 1956. Daily rhythmic activity of the sea-pen, Cavernularia obesz Valeriennes. XIII. Rhythmic change of ammonium content in body fluid. (1). Zool. Mag., 65, 359-361. (in Japanese with English résumé)

\& 1957. do. XIV. do. (2). In press. (in Japanese with English résumé)

TribukAiT, B. 1954. Aktivitätsperiodik der Maus im künstlich verkürzten Tag. Naturwiss., 41, 92-93.

YAMAZAK., H. 1955. Studies on the nervous control in the conduct of mating and oviposition of Lepidopterus moths. Bull. Nagano Sericultural Exp. Sta., 10, 197-242. (in Japanese) 

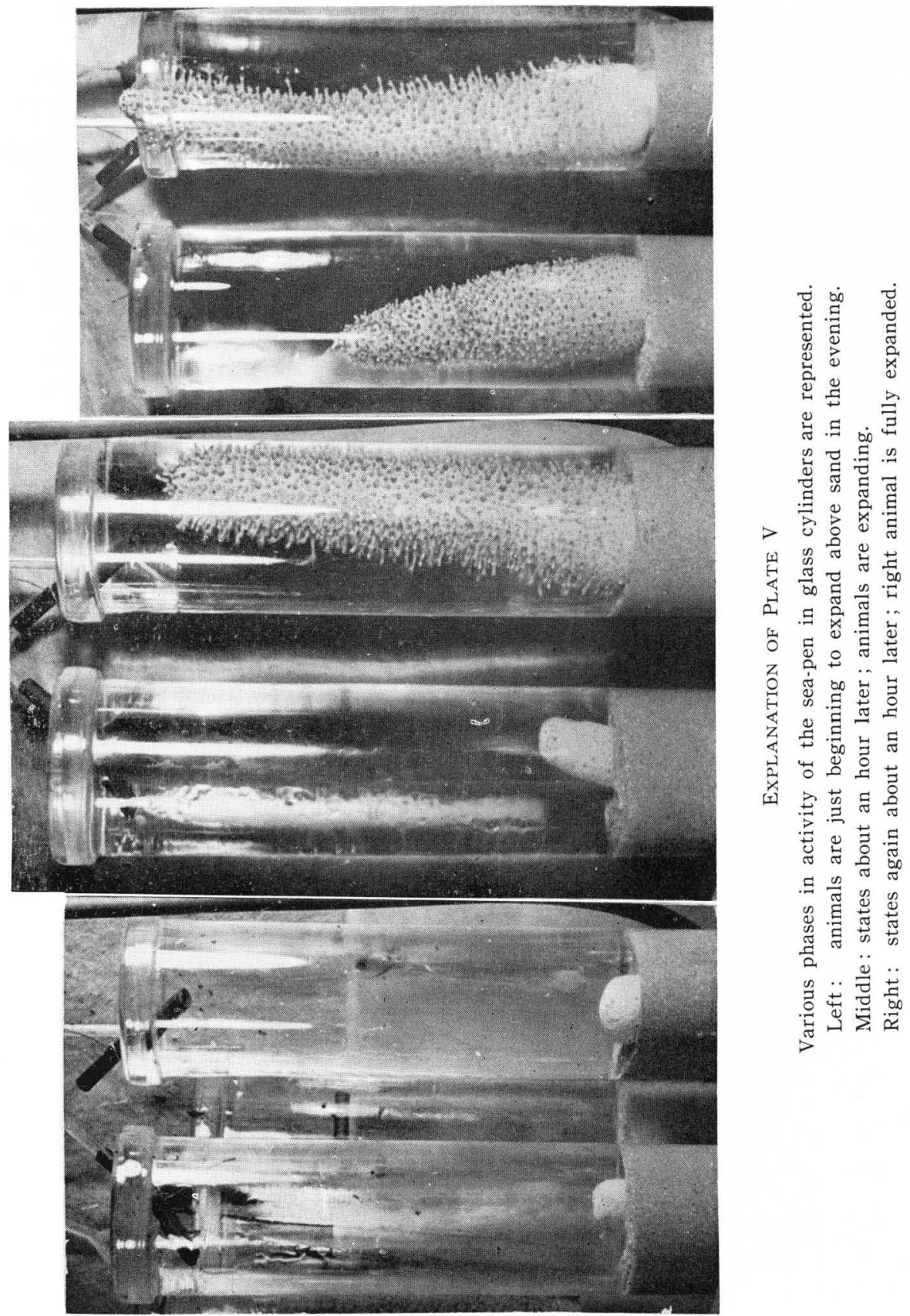

S. Mori \& Y. Ondô: Daily Rhythmic Activity of the Sea-pen, XV. 